\title{
MINI-REVIEW
}

\section{Inflammaging in skin and intrinsic underlying factors}

\author{
Akihiro Aioi
}

Septem-Soken, 2-4-27 Dojima, Kita-ku, Osaka 5300003, Japan.E-mail: a-aioi@septem-so.com

\begin{abstract}
Aging of organs starts from the time of birth and continues throughout life. Aging of skin can be divided into two distinct types - intrinsic aging and extrinsic, based on the fact that the skin is the outermost organ exposed to the external environment. However, despite their different histological features and triggers, intrinsic and extrinsic aging share common biochemical mechanisms. $\beta$-galactosidase, $\mathrm{p} 16^{\mathrm{INK} 4 \mathrm{a}}$, and senescence-associated secretory phenotype (SASP) factors are detected in skin cells as biomarkers of senescence. In particular, inflammatory cytokines, the constituents of SASP, play pivotal roles in "inflammaging" which is a concept involving the relationship between aging and low-grade inflammation. In this review, the features of skin aging and its underlying mechanism of skin aging are summarized. Keywords: SASP; Inflammaging; Skin
\end{abstract}

\section{ARTICLE INFO}

Received 28 October 2021

Accepted 19 November 2021

Available online 24 November 2021

\section{COPYRIGHT}

Copyright $\odot 2021$ Akihiro Aioi.

EnPress Publisher LLC. This work is licensed under the Creative Commons Attribution-NonCommercial 4.0 International License (CC BY-NC 4.0).

https://creativecommons.org/licenses/by-nc/ $4.0 /$

\section{Introduction}

Aging of organs starts from the time when one is born and continues throughout life. Thus, the strategies to prevent chronological tissue dysfunction have become an important issue in increasing elderly societies. Since Hayflick and Moorhead reported the finite proliferative capacity of cultured normal human fibroblasts ${ }^{[1]}$, researchers have contended the involvement of cell senescence in organ aging. However, accumulating evidence has established obvious roles of senescent cells, which are defined by irreversible cell-cycle arrest, resistance to apoptosis, and senescence-associated secretory phenotype (SASP), in physiological and pathological states ${ }^{[2-4]}$.

In the skin, aging can be divided into two distinct types: intrinsic aging and extrinsic aging. Intrinsic aging is an inevitable physiological process and characterized by dry skin, fine wrinkles, and gradual dermal atrophy. On the other hand, extrinsic aging is induced by environmental factors, including air pollution and sun exposure, and is characterized by coarse wrinkles, loss of elasticity, and rough texture appearance ${ }^{[5,6]}$. Similar to other organs, senescent cells accumulate in intrinsically and extrinsically aged skin and contribute to skin aging. In this review, the skin environment of senescent cells is summarized.

\section{Intrinsic skin aging}

Intrinsic skin aging is a process of physiological change involving photo-protected areas. Intrinsically aged skin is clinically characterized by dryness, fine wrinkles, and a histologically thinner epidermis and flattened dermal-epidermal junction ${ }^{[7,8]}$. Clinical features are induced by a significant reduction in surface lipid production with 
chronological aging, whereas stratum corneum hydration and transepidermal water loss are modestly lowered or unchanged ${ }^{[9,10]}$. Thinning of the epidermis is induced by reduction of basal keratinocyte proliferation dependent on reduction of the nutrient flux through age-related flattened dermal-epidermal junctions, in which the area of the available exchange surface is reduced ${ }^{[11,12]}$. In the dermis, there are fewer fibroblasts in aged skin than in young $\operatorname{skin}^{[13]}$. In addition, the production of type I procollagen in intrinsically aged human skin is reduced, depending on the downregulation of TGF- $\beta /$ Smad signaling ${ }^{[14]}$. In addition to aging-induced structural changes, presumably the cutaneous immunity becomes defective with age. A variety of bacterial, fungal, and viral infections markedly increase with age $^{[15-17]}$. Toll-like receptors (TLRs), which are crucial pathogen pattern recognition receptors, are expressed in keratinocytes, fibroblasts, and skin-resident immune cells. Once triggered by ligands, TLRs lead to the production of inflammatory cytokines and initiation of immune responses ${ }^{[18,19]}$. Shaw et al. reported that the expression and function of TLRs diminished with age ${ }^{[20]}$. Furthermore, TLR ligand-induced production of inflammatory cytokines is reduced in circulating dendritic cells in older individuals ${ }^{[21]}$. This indicates that pathogen pattern recognition, which is the primary process of the innate immune system, is attenuated with age. Dendritic cells (DCs), which are the sentinels of the immune system, bridge the innate and adaptive immune system by sequestration and presentation of antigens to T cells. Diverse populations of DCs, including dermal DCs, dermal macrophages in the dermis, and Langerhans cells (LCs) represent DCs in epidermis ${ }^{[22,23]}$. A previous study reported that the absolute number of DCs and their CD $34^{+}$precursors declined with age ${ }^{[24,25]}$. In addition to the reduction in the number of LCs in aged-skin, the migratory ability of LCs in aged skin is impaired because of attenuation of the responses to cytokine gradients, and the subsequent accumulation of LCs in regional lymph nodes is reduced ${ }^{[26-28]}$. In the whole skin of an average person, there are approximately $2 \times 10^{10}$ $\mathrm{T}$ cells, including resident memory $\mathrm{T}$ cells $\left(\mathrm{T}_{\mathrm{RM}}\right)$ and circulating memory $\mathrm{T}$ cells ${ }^{[29]}$. The $\mathrm{CD}^{+} /$ $\mathrm{CD}_{103^{-}} \mathrm{T}_{\mathrm{RM}}$ cells are located in the dermis, whereas
$\mathrm{CD}^{+} / \mathrm{CD} 03^{+}$and $\mathrm{CD} 8^{+} / \mathrm{CD} 103^{+} \mathrm{T}_{\mathrm{RM}}$ cells are enriched in epidermis. Both $\mathrm{CD}^{+} / \mathrm{CD}_{103^{+}}$and $\mathrm{CD} 8^{+} /$ $\mathrm{CD}_{103^{+}} \mathrm{T}_{\mathrm{RM}}$ cells have more potent effector functions than circulating $\mathrm{T}$ cells, but have less proliferative capacity than that of the $\mathrm{CD}_{103^{-}} \mathrm{T}_{\mathrm{RM}}$ cells ${ }^{[30]}$. To investigate antigen-specific $\mathrm{T}$ cell responses, delayed-type hypersensitivity reactions (DTHs) represent the most informative in vivo experimental models. Previous studies have demonstrated that DTHs are impaired in older humans and mice ${ }^{[18,31-33]}$. The proportion of memory phenotype $\mathrm{T}$ cells increases with age and becomes predominant after midlife, whereas the total number of $\mathrm{T}$ cells is maintained throughout life $\mathrm{f}^{[34]}$. Repeated antigen exposure during the lifespan induces exhausted $\mathrm{T}$ cells characterized by telomere shortening and expression of exhaustion markers such as PD1 and $\mathrm{LAG}^{[35]}{ }^{[3]}$ Moreover, continuous homeostatic proliferation induces dysfunctional $\mathrm{CD}^{+} \mathrm{T}$ cells, named senescence-associated $\mathrm{T}$ cells, which are characterized by the expression of PD1 and LAG3, and abundant secretion of inflammatory cytokines. The proportion of senescence-associated $\mathrm{T}$ cells progressively increases with age ${ }^{[36,37]}$. Therefore, it is supposed that age-related dysfunction, including antigen recognition and presentation, and senescence in T cells reflects cutaneous immunity.

\section{Extrinsic skin aging}

Extrinsic aging is caused by several exogenous factors such as tobacco smoke, air pollution and ultraviolet (UV) rays. Out of these factors, UV affects aging the most; therefor, extrinsic aging is referred to as photoaging. UV is classified as UVA, UVB and UVC, depending on the wavelength. UVA $(320-400 \mathrm{~nm})$ and UVB $(280-320 \mathrm{~nm})$ reach the surface of the earth, while UVC (100-280 nm) is absorbed by the ozone layer. Although UVB has higher energy, UVB is mostly absorbed by the epidermis, owing to its shorter wavelength, while UVA, which has a lower energy, can penetrate into the dermis. Therefore, UVB is responsible for acute sunburn reactions in the epidermis, and UVA is considered as a major factor in chronic dermal photoaging. UV-irradiated epidermis thickens, in contrast to the thinner epidermis, is observed in intrinsically aged $\operatorname{skin}^{[38]}$. Tissue renewal in the epi- 
dermis is dependent on proliferative cells in the basal layer, which include keratinocyte stem cells (KSCs) and transit amplifying (TA) cells ${ }^{[39]}$. Although the expression of integrin $\beta 1$, which is a KSC marker, is reduced and the ratio between involucrin, a differentiation marker of keratinocytes, and integrin $\beta 1$ is increased, aberrant suprabasal integrin $\beta 1$ expression and enhanced expression of $\mathrm{Ki}-67$, expressed in proliferating cells, are detected in chronic sun-exposed skin of the elderly. In addition, flow cytometric analysis revealed that integrin $\alpha 6^{\text {bri }} \mathrm{CD} 71^{\text {bri }}$ cell numbers are greater in sun-exposed epidermis than in sun-protected epidermis, suggesting that the proliferation of TA cells is increased in sun-exposed epidermis ${ }^{[40,41]}$. These results suggest that UV exposure induces a hyperproliferative state of epidermis in photoaged skin. Another clinical characteristic is the presence of coarse wrinkles in photoaged skin. Studies have demonstrated that the reduction of collagen type I formation in photodamaged human skin, depending on UV irradiation-induced matrix metalloproteinase (MMP) expression and synthesis inhibition by damaged collagen, contributes to UV irradiationinduced wrinkle formation ${ }^{[42-44]}$. Similarly, the suppression of collagen type IV, a component of the basement membrane, and collagen type VII, an anchoring fibril connecting fibroblasts to the basement membrane, affects wrinkle formation, because of weakening of the dermal-epidermal junc$\operatorname{tion}^{[45,46]}$.

\section{Senescent cell biomarkers}

Cellular senescence was first described as the finite proliferative capacity of cultured normal human fibroblasts ${ }^{[1]}$. Irreversible cell growth arrest occurs due to DNA damage, telomere shortening ${ }^{[47]}$, and oncogenic stress ${ }^{[48]}$. As removing senescent cells from aging tissues can delay tissue dysfunction and lead to prolonged lifespan, obvious biomarkers to identify senescent cells have been sought. The activity of $\beta$-galactosidase ( $\beta$-gal) at $\mathrm{pH} 6$ is increased in middle-late passage cultured fibroblasts and keratinocytes, whereas terminally differentiated keratinocytes do not express $\beta$-gal at $\mathrm{pH}$ 6. Activity in skin sections from the different age groups increases with age, suggesting that se- nescent cells accumulate in vivo with age ${ }^{[49]}$. Thus, the $\beta$-gal activity is termed senescence-associated $\beta$-gal (SA- $\beta$-gal) activity and remains the gold standard for identifying senescent cells in culture and in tissue samples. As senescent cells are irreversibly arrested, cell cycle regulators are usually employed to detect senescent cells. p16 $6^{\mathrm{INK} 4 \mathrm{a}}$, encoded by the Ink4a/Arf locus, is a tumor growth suppressor. In normal human keratinocytes, $\mathrm{p} 16^{\mathrm{INK} 4 \mathrm{a}}$, which is upregulated by single or repeated UVB irradiation, plays a role in cell cycle regulation ${ }^{[50]}$. The expression of $\mathrm{p} 16^{\mathrm{INK} 4 \mathrm{a}}$ markedly increases with advancing age in mice and humans, suggesting that $\mathrm{p} 16^{\mathrm{INK} 4 \mathrm{a}}$ is a cellular senescence marker ${ }^{[51,52]}$. A previous study showed that the number of $\mathrm{p} 16^{\mathrm{INK} 4 \mathrm{a}}$ positive cells increases with age in the skin and that numerous cardiovascular diseases are significantly associated with tertiles of $\mathrm{p} 16^{\mathrm{INK} 4 \mathrm{a}}$ positive cells in epidermal cells, suggesting an association between cell senescence and age-related pathology ${ }^{[53]}$. Previous studies have demonstrated that nuclear senescence-associated events such as heterochromatin loss, remodeling of the nuclear lamina, and DNA methylation are involved in cell proliferation ${ }^{[54-57]}$. Senescent cells secrete senescence-associated secretory phenotype (SASP) factors, including inflammatory cytokines, chemokines, MMPs and growth factors. The presence of SASP factors such as MMP3, MMP9, IL-6, IL-8, and insulin-like growth factor binding protein 7 has been used as a marker for senescent dermal fibroblasts and melanocytes ${ }^{[58-60]}$. The release of SASP factors is facilitated by the translocation of high mobility group box-1 (HMGB1) proteins from the nucleus to the cytoplasm and extracellular space in senescent cells ${ }^{[61,62]}$. While molecular hallmarks of cell senescence have been characterized in vitro, Lupa et al. demonstrated a correlation between SASP expression and age in intrinsically-aged human dermal fibroblasts, suggesting that SASP expression is upregulated along with chronological aging in vivo ${ }^{[63]}$. Collectively, senescent cells, which are considered passive bystanders, modulate their environment by secretion of SASP factors in both in vitro and in vivo (Figure 1). 


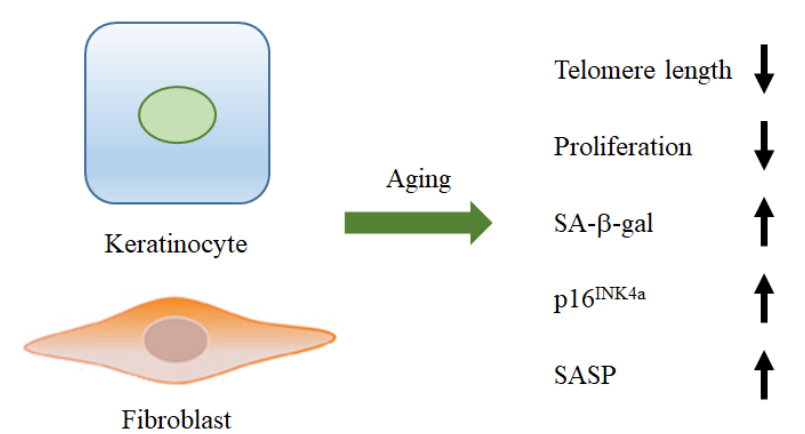

Figure 1. Senescent cell biomarkers. Shortened telomeres, reduction of cell proliferative capacity, and increased SA- $\beta$-gal activity, $\mathrm{p} 16^{\mathrm{INK} 4 \mathrm{a}}$ expression, and SASP production.

\section{Inflammaging}

Since Franceschi et al. used the term "Inflamm-aging",[64], similar terms such as "inflammaging" and various other concepts have been proposed $^{[65-70]}$. Despite of confusion regarding definitions and terminology, there is consensus that inflammaging refers to low-grade, chronic, and asymptomatic inflammation, and that the primary feature of inflammaging is an increase in proinflammatory status with advancing age ${ }^{[71]}$. Several factors are involved in the underlying mechanism of inflammaging ${ }^{[69,72-77]}$. Inflammatory cytokines, which are constituents of SASP, play pivotal roles in inflammation. Previous studies have suggested that complex processes are involved in the upregulation of inflammatory cytokine expression. Although $\mathrm{p} 16^{\mathrm{INK} 4 \mathrm{a}}$ is sufficient to induce senescent cell cycle arrest ${ }^{[78]}$, precipitating DNA damage leads to the upregulation of inflammatory cytokines, suggesting that the mechanism of inflammatory cytokine production is distinct from that of senescent cell cycle arrest. Studies have also demonstrated that the upregulation of inflammatory cytokine expression is triggered by activated ataxia telangiectasia mutated (ATM)-mediated DNA damage responses $^{[79,80]}$. In addition to the DNA-damage response pathway, p38MAPK and protein kinase D1 are involved in the production of inflammatory cytokines. DNA-damage responses and kinases induce phosphorylation of NFkB p65/RelA subunit, followed by translocation to the nucleus where it binds to the promoters of inflammatory cytokine genes, regulating their induction during senescence ${ }^{[81-83]}$. In addition to NFKB, CCAAT/ enhancer binding protein $\beta$ (CEBP $\beta)$, which is regulated by the mitogen-activated protein kinase (MAPK) pathway, participates in inflammatory cytokine production. Sebastian et al. showed that CEBP $\beta$ is critical for cell senescence in mouse embryonic fibroblasts ${ }^{[84]}$. Following the activation of transcription factors, it is supposed that IL- $1 \alpha$ paracrinally regulates the production of SASP production as an upstream modulator. Previous studies have shown that IL- $1 \alpha$ is essential for inducing the production of IL-6 and IL- $8^{[85,86]}$. Consequently, low-grade chronic inflammation reinforces senescence via cell growth arrest and disruption of stem cell function $^{[58,59,87,88]}$. Similar to the regulation of SASP production in intrinsic aging, previous studies have demonstrated that UVB irradiation, which is a major stimulus in extrinsic aging (photoaging), is involved in SASP regulation, such as the production of IL-6 and IL-8, activation of NFKB, activation of insulin-like growth factor-1 receptor, and HMGB1 release ${ }^{[89-92]}$. In contrast, sirtuin 1 (SIRT1), which is one of the regulators of wound healing ${ }^{[93]}$, suppresses inflammatory cytokines by binding to the promoter regions of inflammatory cytokine genes ${ }^{[93,95]}$. However, because these studies were performed in vitro, it is necessary to perform in vivo experiments with a dose of UVB that meets the definition of inflammaging as asymptomatic (Figure 2).

\section{Conclusions}

Despite their different histological features and triggers, intrinsic and extrinsic aging share common biochemical mechanisms. In particular, regulation of inflammatory cytokine production is considered an important therapeutic strategy not only for acute inflammation caused by UV irradiation, but also for anti-aging. On the other hand, from a literature search regrading senescent cells, a question arose that cellular aging in the epidermis and aging in other organs should be distinguished. According to the definition of senescent cells, the cells are denoted exhibiting stable and long-term loss of proliferative capacity, and are distinguished from terminally differentiated cells. As KSCs and TA cells still have proliferative capacity, whereas senescence biomarkers are detected in the epidermis, the microenvironment surrounding KSCs and TA cells should 
be addressed to explore the specific conditions in- volving the epidermis in the future.

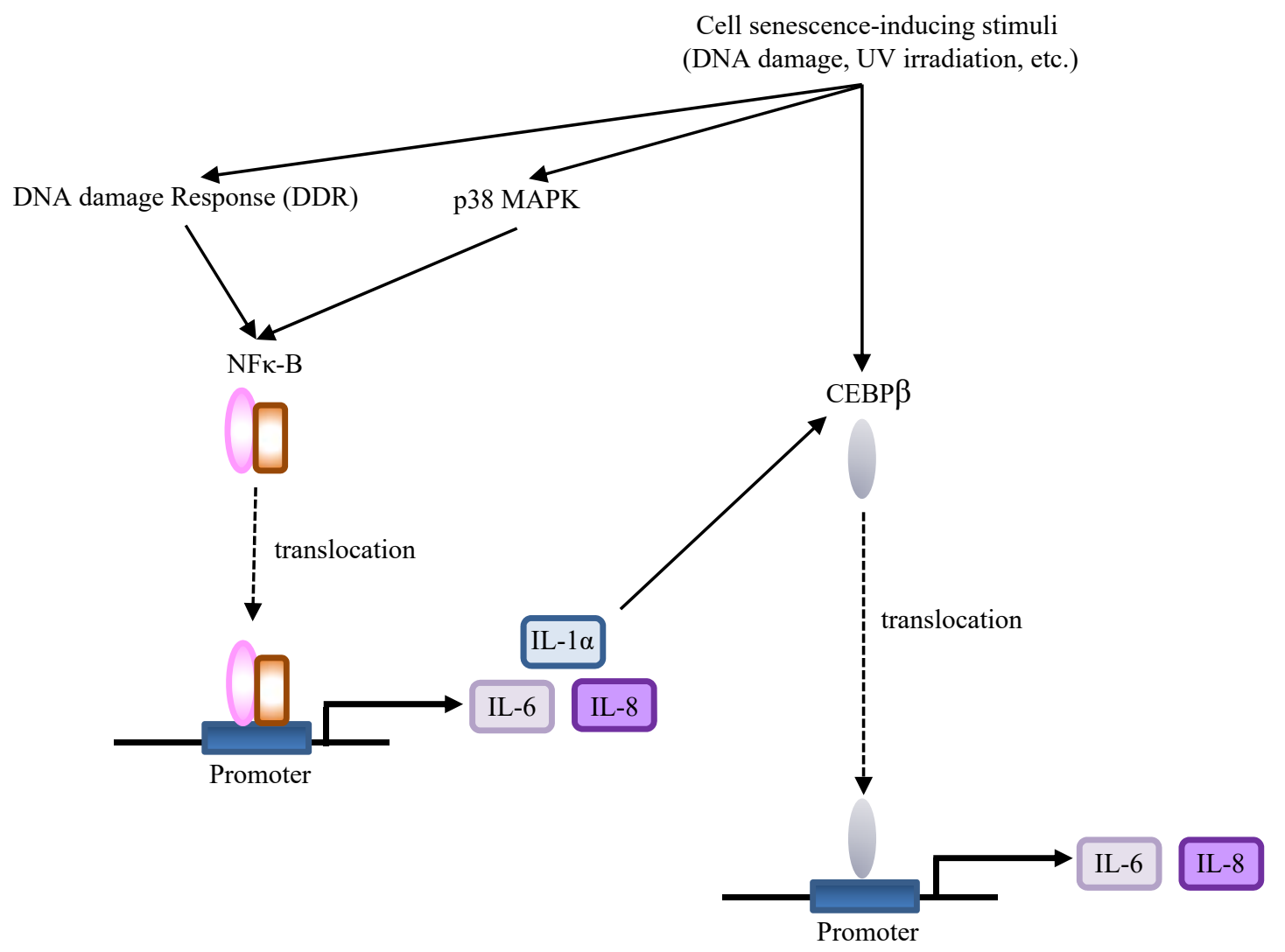

Figure 2. Inflammatory cytokine regulatory pathways. Senescence-inducing stimuli induce DDR and p38MAPK activation, followed by phosphorylation of NFK-B. Phosphorylated NFK-B translocates to the nucleus and then binds to the promoter regions of inflammatory cytokines genes. Consequently, the production of inflammatory cytokines is enhanced. Senescence-inducing stimuli and IL- $1 \alpha$, which is induced in the NFא-B pathway, directly activate CEBP $\beta$. Activated CEBP $\beta$ translocates to the nucleus and induces the expression of IL-6 and IL-8 expression.

\section{Conflict of interest}

There is no conflict of interest in this review.

\section{Acknowledgements}

We would like to thank Editage (https://www. editage.com/) for English language editing.

\section{References}

1. Hayflick L, Moorhead PS. The serial cultivation of human diploid cell strains. Experimental Cell Research 1961; 25(3): 585-621.

2. Campisi J, d'Adda di Fagagna F. Cellular senescence: when bad things happen to good cells. Nature reviews Molecular cell biology 2007; 8(9): 729-740. doi: 10.1038/nrm2233

3. Kuilman T, Michaloglou C, Mooi WJ, et al. The essence of senescence. Genes \& Development 2010; 24(22): 2463-2479. doi: 10.1101/gad.1971610

4. He S, Sharpless NE. Senescence in health and dis- ease. Cell 2017; 169(6): 1000-1011. doi: 10.1016/j.cell.2017.05.015

5. Krutmann J, Bouloc A, Sore G, et al. The skin aging exposome. Journal of Dermatological Science 2017; 85(3): 152-161. doi: 10.1016/j.jdermsci.2016.09.015

6. Mora Huertas AC, Schmelzer CE, Hoehenwarter W, et al. Molecular-level insights into aging processes of skin elastin. Biochimie 2016; 128-129: 163-173. doi: 10.1016/j.biochi.2016.08.010

7. Kligman AM. Perspectives and problems in cutaneous gerontology. Journal of Investigative Dermatology 1979; 73(1): 39-46. doi: 10.1111/1523-1747.ep12532758

8. Lavker RM, Zheng P, Dong G. Aged skin: A study by light, transmission electron, and scanning electron microscopy. Journal of Investigative Dermatology 1987; 88(S3): 44s-51s. doi:

10.1111/1523-1747.ep12468934

9. Luebberding S, Krueger N, Kerscher M. 
Age-related changes in skin barrier func-

tion - quantitative evaluation of 150 female subjects. International Journal of Cosmetic Science 2013; 35(2): 183-190. doi: 10.1111/ics.12024

10. Man M, Xin S, Song S, et al. Variation of skin surface $\mathrm{pH}$, sebum content and stratum corneum hydration with age and gender in a large Chinese population. Skin Pharmacol Physiol 2009; 22(4): 190199. doi: 10.1159/000231524

11. Makrantonaki E, Zouboulis CC, William J. Cunliffe Scientific Awards. Characteristics and pathomechanisms of endogenously aged skin. Dermatology 2007; 214: 352-360. doi: 10.1159/000100890

12. Moragas A, Castells C, Sans M. Mathematical morphologic analysis of aging-related epidermal changes. Analytical and Quantitative Cytology and Histology 1993; 15(2): 75-82.

13. Kohl E, Steinbauer J, Landthaler M, et al. Skin ageing. Journal of the European Academy of Dermatology and Venereology 2011; 25(8): 873-884. doi: 10.1111/j.1468-3083.2010.03963.x

14. Quan T, Shao Y, He T, et al. Reduced expression of connective tissue growth factor (CTGF/CCN2) mediates collagen loss in chronologically aged human skin. Journal of Investigative Dermatology 2010; 130(2): 415-424. doi: 10.1038/jid.2009.224

15. Castro MCR, Ramos-E-Silva M. Cutaneous infections in the mature patient. Clinics in Dermatology 2018; 36(2): 188-196. doi: 10.1016/j.clindermatol.2017.10.010

16. Laube S. Skin infections and ageing. Ageing Research Reviews 2004; 3(1): 69-89. doi: 10.1016/j.arr.2003.08.003

17. Wessman LL, Andersen LK, Davis MDP. Incidence of diseases primarily affecting the skin by age group: population-based epidemiologic study in Olmsted County, Minnesota, and comparison with age-specific incidence rates worldwide. International Journal of Dermatology 2018; 57(9): 10211034. doi: 10.1111/ijd.13904

18. Vukmanovic-Stejic M, Rustin MHA, Nikolich-Zugich $\mathrm{J}$, et al. Immune responses in the skin in old age. Current Opinion in Immunology 2011; 23(4): 525-531. doi: 10.1016/j.coi.2011.05.008
19. Fitzgerald KA, Kagan JC. Toll-like receptors and the control of immunity. Cell 2020; 180(6): 10441066. doi: 10.1016/j.cell.2020.02.041

20. Shaw AC, Panda A, Joshi SR, et al. Dysregulation of human toll-like receptor function in aging. Ageing Research Reviews 2011; 10(3): 346-353. doi: 10.1016/j.arr.2010.10.007

21. Panda A, Qian F, Mohanty S, et al. Age-associated decrease in TLR function in primary human dendritic cells predicts influenza vaccine response. The Journal of Immunology 2010; 184(5): 2518-2527. doi: 10.4049/jimmunol.0901022

22. West HC, Bennett CL. Redefining the role of Langerhans cells as immune regulators within the skin. Frontiers in Immunology 2017; 8: 1941. doi: 10.3389/fimmu.2017.01941

23. Chambers ES, Vukmanovic-Stejic M. Skin barrier immunity and ageing. Immunology 2020; 160(2): 116-125. doi: 10.1111/imm. 13152

24. Della Bella S, Bierti L, Presicce P, et al. Peripheral blood dendritic cells and monocytes are differently regulated in the elderly. Clinical Immunology 2007; 122(2): 220-228. doi: 10.1016/j.clim.2006.09.012

25. Mahbub S, Brubaker AL, Kovacs EJ. Aging of the innate immune system: an update. Current Immunology Reviews 2011; 7(1): 104-115. doi: $10.2174 / 157339511794474181$

26. Cumberbatch M, Dearman RJ, Kimber I. Influence of ageing on Langerhans cell migration in mice: identification of a putative deficiency of epidermal interleukin-1 $\beta$. Immunology 2002; 105(4): 466-477. doi: 10.1046/j.1365-2567.2002.01381.x

27. Pilkington SM, Ogden S, Eaton LH, et al. Lower levels of interleukin- $1 \beta$ gene expression are associated with impaired Langerhans' cell migration in aged human skin. Immunology 2018; 153(1): 60-70. doi: $10.1111 / \mathrm{imm} .12810$

28. Grolleau-Julius A, Harning EK, Abernathy LM, et al. Impaired dendritic cell function in aging leads to defective antitumor immunity. Cancer research 2008; 68(15): 6341-6349. doi: 10.1158/0008-5472.CAN-07-5769

29. Clark RA, Chong B, Mirchandani N, et al. The vast majority of $\mathrm{CLA}^{+} \mathrm{T}$ cells are resident in normal skin. 
The Journal of Immunology 2006; 176(7): 44314439. doi: 10.4049/jimmunol.176.7.4431

30. Watanabe R, Gehad A, Yang C, et al. Human skin is protected by four functionally and phenotypically discrete populations of resident and recirculating memory T cells. Science Translational Medicine 2015; 7(279): 279ra39. doi:

10.1126/scitranslmed.3010302

31. Vissinga C, Nagelkerken L, Zijlstra J, et al. A decreased functional capacity of $\mathrm{CD}^{+} \mathrm{T}$ cells underlies the impaired DTH reactivity in old mice. Mechanisms of Ageing and Development 1990; 53(2): 127-139. doi: 10.1016/0047-6374(90)90065-n

32. Toichi E, Hanada K, Hosokawa T, et al. Age-related decline in humoral immunity caused by the selective loss of TH cells and decline in cellular immunity caused by the impaired migration of inflammatory cells without a loss of TDTH cells in SAMP1 mice. Mech. Mechanisms of Ageing and Development 1997; 99(3): 199-217. doi: 10.1016/s0047-6374(97)00100-0

33. Castle SC, Norman DC, Perls TT, et al. Analysis of cutaneous delayed-type hypersensitivity reaction and $\mathrm{T}$ cell proliferative response in elderly nursing home patients: an approach to identifying immunodeficient patients. Gerontology 1990; 36(4): $217-$ 229. doi: 10.1159/000213203

34. Surh CD, Sprent J. Homeostasis of naive and memory T cells. Immunity 2008; 29(6): 848-862. doi: 10.1016/j.immuni.2008.11.002

35. Akbar AN, Henson SM. Are senescence and exhaustion intertwined or unrelated processes that compromise immunity? Nature Reviews Immunology 2011; 11(4): 289-295. doi: 10.1038/nri2959

36. Minato N, Hattori M, Hamazaki Y. Physiology and pathology of T-cell aging. International Immunology 2020; 32(4): 223-231. doi:

10.1093/intimm/dxaa006

37. Thomas R, Wang W, Su D. Contributions of age-related thymic involution to immunosenescence and inflammaging. Immunity \& Ageing 2020; 17(1): 1-17. doi: 10.1186/s12979-020-0173-8

38. Kligman LH. Photoaging: manifestations, prevention, and treatment. Clinics in Geriatric Medicine
1989; 5(1): 235-251. doi: 10.1016/S0749-0690(18)30708-0

39. Kaur P. Interfollicular epidermal stem cells: identification, challenges, potential. Journal of Investigative Dermatology 2006; 126(7): 1450-1458.

40. Bosset S, Bonnet-Duquennoy M, Barré P, et al. Decreased expression of keratinocyte $\beta 1$ integrins in chronically sun-exposed skin in vivo. British Journal of Dermatology 2003; 148(4): 770-778. doi: 10.1046/j.1365-2133.2003.05159.x

41. Kwon OS, Yoo HG, Han JH, et al. Photoaging-associated changes in epidermal proliferative cell fractions in vivo. Archives of Dermatological Research 2008; 300(1): 47-52. doi: 10.1007/s00403-007-0812-3

42. Griffiths CE, Russman AN, Majmudar G, et al. Restoration of collagen formation in photodamaged human skin by tretinoin (retinoic acid). New England Journal of Medicine 1993; 329(8): 530-535. doi: 10.1056/NEJM199308193290803

43. Fisher GJ, Wang Z, Datta SC, et al. Pathophysiology of premature skin aging induced by ultraviolet light. New England Journal of Medicine 1997; 337(20): 1419-1428. doi: 10.1056/NEJM199711133372003

44. Varani J, Spearman D, Perone P, et al. Inhibition of type I procollagen synthesis by damaged collagen in photoaged skin and by collagenase-degraded collagen in vitro. The American Journal of Pathology 2001; 158(3): 931-942. doi: 10.1016/S0002-9440(10)64040-0

45. Craven NM, Watson RE, Jones CJ, et al. Clinical features of photodamaged human skin are associated with a reduction in collagen VII. British Journal of Dermatology 1997; 137(3): 344-350.

46. Contet-Audonneau JL, Jeanmaire C, Pauly G. A histological study of human wrinkle structures: comparison between sun-exposed areas of the face, with or without wrinkles, and sun-protected areas. British Journal of Dermatology 1999; 140(6): 1038-1047. doi: 10.1046/j.1365-2133.1999.02901.x

47. d'Adda di Fagagna F, Reaper PM, Clay-Farrace L, et al. A DNA damage checkpoint response in telomere-initiated senescence. Nature 2003; 426(6963): 
194-198. doi: 10.1038/nature02118

48. Serrano M, Lin AW, McCurrach ME, et al. Oncogenic RAS provokes premature cell senescence associated with accumulation of p53 and p16(INK4a). Cell 1997; 88(5): 593-602. doi: 10.1016/S0092-8674(00)81902-9

49. Dimri GP, Lee X, Basile G, et al. A biomarker that identifies senescent human cells in culture and in aging skin in vivo. Proceedings of the National Academy of Sciences 1995; 92(20): 9363-9367. doi: 10.1073/pnas.92.20.9363

50. Chazal M, Marionnet C, Michel L, et al. P16(INK4A) is implicated in both the immediate and adaptative response of human keratinocytes to UVB irradiation. Oncogene 2002; 21(17): 26522661. doi: 10.1038/sj.onc.1205349

51. Krishnamurthy J, Torrice C, Ramsey MR, et al. Ink4a/Arf expression is a biomarker of aging. The Journal of Clinical Investigation 2004; 114(9): 1299-1307. doi: 10.1172/JCI22475

52. Ressler S, Bartkova J, Niederegger $\mathrm{H}$, et al. $\mathrm{p} 16^{\mathrm{INK} 4 \mathrm{~A}}$ is a robust in vivo biomarker of cellular aging in human skin. Aging Cell 2006; 5(5): 379 389. doi: 10.1111/j.1474-9726.2006.00231.x

53. Waaijer MEC, Parish WE, Strongitharm BH, et al. The number of $\mathrm{p} 16^{\mathrm{INK} 4 \mathrm{a}}$ positive cells in human skin reflects biological age. Aging Cell 2012;

11(4): 722-725. doi: 10.1111/j.1474-9726.2012.00837.x

54. Wang AS, Dreesen O. Biomarkers of cellular senescence and skin aging. Frontiers in Genetics 2018; 9: 247. doi: 10.3389/fgene.2018.00247

55. Tsurumi A, Li WX. Global heterochromatin loss: a unifying theory of aging? Epigenetics 2012; 7(7): 680-688. doi: 10.4161/epi.20540

56. Dreesen O, Stewart CL. Accelerated aging syndromes, are they relevant to normal human aging? Aging (Albany NY) 2011; 3(9): 889-895. doi: 10.18632/aging.100383

57. Grönniger E, Weber B, Heil O, et al. Aging and chronic sun exposure cause distinct epigenetic changes in human skin. PLoS Genetics 2010; 6(5): e1000971. doi: 10.1371/journal.pgen.1000971

58. Acosta JC, O'Loghlen A, Banito A, et al. Chemokine signaling via the $\mathrm{CXCR} 2$ receptor reinforces senescence. Cell 2008; 133(6): 1006-1018. doi: 10.1016/j.cell.2008.03.038

59. Kuilman T, Michaloglou C, Vredeveld LCW, et al. Oncogene-induced senescence relayed by an interleukin-dependent inflammatory network. Cell 2008; 133(6): 1019-1031. doi: 10.1016/j.cell.2008.03.039

60. Wajapeyee N, Serra RW, Zhu X, et al. Oncogenic BRAF induces senescence and apoptosis through pathways mediated by the secreted protein IGFBP7. Cell 2008; 132(3): 363-374. doi: 10.1016/j.cell.2007.12.032

61. Davalos AR, Kawahara M, Malhotra GK, et al. p53-dependent release of Alarmin HMGB1 is a central mediator of senescent phenotypes. Journal of Cell Biology 2013; 201(4): 613-629. doi: 10.1083/jcb.201206006

62. Biran A, Zada L, Abou Karam P, et al. Quantitative identification of senescent cells in aging and disease. Aging Cell 2017; 16(4): 661-671. doi: 10.1111/acel.12592

63. Waldera Lupa DM, Kalfalah F, Safferling K, et al. Characterization of skin aging-associated secreted proteins (SAASP) produced by dermal fibroblasts isolated from intrinsically aged human skin. Journal of Investigative Dermatology 2015; 135(8): 19541968. doi: 10.1038/jid.2015.120

64. Franceschi C, Bonafè M, Valensin S, et al. Inflamm-aging: An evolutionary perspective on immunosenescence. Annals of the New York Academy of Sciences 2000; 908(1): 244-254. doi: 10.1111/j.1749-6632.2000.tb06651.x

65. Giunta B, Fernandez F, Nikolic WV, et al. Inflammaging as a prodrome to Alzheimer's disease. Journal of Neuroinflammation 2008; 5(1): 1-15. doi: 10.1186/1742-2094-5-51

66. De Martinis M, Franceschi C, Monti D, et al. Inflamm-ageing and lifelong antigenic load as major determinants of ageing rate and longevity. FEBS Letters 2005; 579(10): 2035-2039. doi: 10.1016/j.febslet.2005.02.055

67. Salminen A, Huuskonen J, Ojala J, et al. Activation of innate immunity system during aging: NF- $\kappa B$ signaling is the molecular culprit of inflamm-aging. Ageing Research Reviews 2008; 7(2): 83-105. doi: 10.1016/j.arr.2007.09.002 
68. Mishto M, Santoro A, Bellavista E, et al. Immunoproteasomes and immunosenescence. Ageing Research Reviews 2003; 2(4): 419-432. doi: 10.1016/s1568-1637(03)00030-8

69. Fuente MDI, Miquel J. An update of the oxidation-inflammation theory of aging: the involvement of the immune system in oxi-inflamm-aging. Current Pharmaceutical Design 2009; 15(26): 30033026. doi: 10.2174/138161209789058110

70. Fulop T, Larbi A, Dupuis G, et al. Immunosenescence and inflamm-aging as two sides of the same coin: friends or foes? Frontiers in Immunology 2017; 8: 1960. doi: 10.3389/fimmu.2017.01960.

71. Xia S, Zhang X, Zheng S, et al. An update on inflamm-aging: mechanisms, prevention, and treatment. Journal of Immunology Research 2016; 2016: 8426874. doi: 10.1155/2016/8426874

72. Butcher SK, Lord JM. Stress responses and innate immunity: aging as a contributory factor. Aging Cell 2004; 3(4): 151-160. doi: 10.1111/j.1474-9728.2004.00103.x

73. Salvioli S, Capri M, Valensin S, et al. Inflamm-aging, cytokines and aging: state of the art, new hypotheses on the role of mitochondria and new perspectives from systems biology. Current Pharmaceutical Design 2006; 12(24): 3161-3171. doi: 10.2174/138161206777947470

74. Hewitt G, Jurk D, Marques FDM, et al. Telomeres are favoured targets of a persistent DNA damage response in ageing and stress-induced senescence. Nature Communications 2012; 3(1): 1-9. doi: 10.1038/ncomms 1708

75. Olivieri F, Albertini MC, Orciani M, et al. DNA damage response (DDR) and senescence: shuttled inflamma-miRNAs on the stage of inflamm-aging. Oncotarget 2015; 6(34): 35509-35521. doi: 10.18632/oncotarget.5899

76. Juhász G, Erdi B, Sass M, et al. Atg7-dependent autophagy promotes neuronal health, stress tolerance, and longevity but is dispensable for metamorphosis in Drosophila. Genes \& Development 2007; 21(23): 3061-3066. doi: $10.1101 / \mathrm{gad} .1600707$

77. Jones DL, Rando TA. Emerging models and paradigms for stem cell ageing. Nature Cell Biology
2011; 13(5): 506-512. doi: 10.1038/ncb0511-506

78. Coppé JP, Rodier F, Patil CK, et al. Tumor suppressor and aging biomarker p16(INK4a) induces cellular senescence without the associated inflammatory secretory phenotype. Journal of Biological Chemistry 2011; 286(42): 36396-36403. doi: 10.1074/jbc.M111.257071

79. Rodier F, Coppé JP, Patil CK, et al. Persistent DNA damage signalling triggers senescence-associated inflammatory cytokine secretion. Nature Cell Biology 2009; 11(8): 973-979. doi: 10.1038/ncb1909

80. Di Micco R, Fumagalli M, Cicalese A, et al. Oncogene-induced senescence is a DNA damage response triggered by DNA hyper-replication. Nature 2006; 444(7119): 638-642. doi:

10.1038 /nature 05327

81. Freund A, Patil CK, Campisi J. p38MAPK is a novel DNA damage response independent regulator of the senescence-associated secretory phenotype. The EMBO Journal 2011; 30(8): 1536-1548. doi: 10.1038/emboj.2011.69

82. Wang P, Han L, Shen H, et al. Protein kinase D1 is essential for Ras-induced senescence and tumor suppression by regulating senescence-associated inflammation. Proceedings of the National Academy of Sciences 2014; 111(21): 7683-7688. doi: 10.1073/pnas.1310972111

83. Ghosh K, Capell BC. The senescence-associated secretory phenotype: critical effector in skin cancer and aging. Journal of Investigative Dermatology 2016; 136(11): 2133-2139. doi: 10.1016/j.jid.2016.06.621

84. Sebastian T, Malik R, Thomas S, et al. C/EBP $\beta$ cooperates with RB:E2F to implement $\mathrm{Ras}^{\mathrm{V} 12}$-induced cellular senescence. The EMBO Journal 2005; 24(18): 3301-3312. doi: 10.1038/sj.emboj.7600789

85. Orjalo AV, Bhaumik D, Gengler BK, et al. Cell surface-bound IL-1 $\alpha$ is an upstream regulator of the senescence-associated IL-6/IL-8 cytokine network. Proceedings of the National Academy of Sciences 2009; 106(40): 17031-17036. doi: 10.1073/pnas.0905299106

86. Acosta JC, Banito A, Wuestefeld T, et al. A complex secretory program orchestrated by the inflam- 
masome controls paracrine senescence. Nature Cell Biology 2013; 15(8): 978-990. doi:

$10.1038 /$ ncb2784

87. Freund A, Orjalo AV, Desprez PY, et al. Inflammatory networks during cellular senescence: causes and consequences. Trends in Molecular Medicine 2010; 16(5): 238-246. doi:

10.1016/j.molmed.2010.03.003

88. Carlson ME, Conboy IM. Loss of stem cell regenerative capacity within aged niches. Aging Cell 2007; 6(3): 371-382. doi: 10.1111/j.1474-9726.2007.00286.x

89. Storey A, McArdle F, Friedmann PS, et al. Eicosapentaenoic acid and docosahexaenoic acid reduce UVB- and TNF- $\alpha$-induced IL- 8 secretion in keratinocytes and UVB-induced IL- 8 in fibroblasts. Journal of Investigative Dermatology 2005; 124(1): 248-255. doi: 10.1111/j.0022-202X.2004.23543.x

90. Lewis DA, Spandau DF. UVB-induced activation of $\mathrm{NF}-\kappa \mathrm{B}$ is regulated by the IGF-1R and dependent on p38 MAPK. Journal of Investigative Dermatology 2008; 128(4): 1022-1029. doi: 10.1038/sj.jid.5701127
91. Lewis DA, Yi Q, Travers JB, et al. UVB-induced senescence in human keratinocytes requires a functional insulin-like growth factor-1 receptor and p53. Molecular Biology of the Cell 2008; 19(4): 13461353. doi: 10.1091/mbc.e07-10-1041

92. Johnson KE, Wulff BC, Oberyszyn TM, et al. Ultraviolet light exposure stimulates HMGB1 release by keratinocytes. Archives of Dermatological Research 2013; 305(9): 805-815. doi: 10.1007/s00403-013-1401-2

93. Aioi A. Sirtuins in wound healing. Trends in Immunotherapy. 2019; 3(2): 89-95. doi: 10.24294/ti.v3.i2.122

94. Hayakawa T, Iwai M, Aoki S, et al. SIRT1 suppresses the senescence-associated secretory phenotype through epigenetic gene regulation. PloS ONE 2015; 10(1): e0116480. doi: 10.1371/journal.pone.0116480

95. Kim HK. Protective effect of garlic on cellular senescence in UVB-exposed HaCaT human keratinocytes. Nutrients 2016; 8(8): 464. doi: 10.3390/nu8080464 